\title{
ОБЕСПЕЧЕНИЕ ПРОДОВОЛЬСТВЕННОЙ БЕЗОПАСНОСТИ СССР ВО ВРЕМЯ ВЕЛИКОЙ ОТЕЧЕСТВЕННОЙ ВОЙНЫ
}

\begin{abstract}
Аннотация: Рассматриваются факторы, позволившие Советскому Союзу обеспечить свою продовольственную безопасность накануне и во время Великой Отечественной войны. Показывается, что сельскохозяйственная экономика, созданная в СССР в 1930-х г2. имела значительный мобилизационный ресурс, позволивший организовать её успешное функиионирование в условиях блицкрига и тотальной войны. Отмечается роль в этом предвоенного патриотического и ударнического движения. Рассказывается о вкладе видных деятелей сельскохозяйственной науки СССР в обеспечение, во время войны, населения продовольствием, а промышленности - требуемым растительным сырьём.
\end{abstract}

Ключевые слова: Экономика, сельское хозяйство, история СССР, Великая Отечественная война, агротехника, селекиия, коллективизация, индустриализация, семеноводство, продовольственная безопасность

\section{Предвоенная сельскохозяйственная политика}

конца 1920-х гг. руководство Советского Союза взяло курс на форсированное развитие тяжёлой промышленности и сельского хозяйства страны. Это было вызвано, прежде всего, сложившейся после Первой мировой войны напряжённой международной обстановкой. Версальские соглашения 1919 года, навязанные странами Антанты побеждённым центральным державам, не устранили противоречий между ними, а неестественные границы и невыполнимые репарационные требования провоцировали возобновление конфликта в недалёком будущем. Ллойд-Джордж, премьер- министр Англии в 1916- 22 гг., называл Версальские соглашения «договором, который гарантирует нам войну через двадцать лет». Для СССР, помимо этих факторов, источниками постоянной напряжённости были отношения с Польшей, захватившей, в результате войны 1919- 21 гг., значительную часть территории Украины и Белоруссии, и Японией, проводившей агрессивно- экспансионистскую политику в Манчжурии. При этом промышленно- экономический статус СССР конца 1920-х гг. среди мировых держав характеризовался известными словами: «Мы отстали от ведущих стран на 50-100 лет. Либо мы пробежим их за десятилетие, либо нас сомнут».

Экономика царской России в конце XIX - XX вв. развивалась быстро, но всё же существенно отставала от ведущих стран Запада. Так, за предвоенные двадцать лет (1893 - 1913 гг.) среднегодовой прирост промышленной продукции составлял 9\%. В 1870 -
1900 гг. в России значительно выросла добыча сырья: каменного угля в 23 раза, нефти в 20 раз; в 7 раз возросла выплавка чугуна. По этим показателям Россия сравнялась или стала опережать ведущие западные страны. Однако, что касается конечных продуктов промышленности, дела обстояли иначе. В 1910-х гг. автомобилей в России производилось за год меньше, чем в США за неделю; авиамоторов за год - как во Франции за 4-5 дней. В 1913 г. в США имелось более 3 млн. абонентов телефонной сети, в России - менее 100 тысяч. По энерго- и механовооруженности Россия отставала от США в 10 раз, от Англии - в 5, от Германии - в 4 раза.

Низким был уровень урожайности, агрокультуры и механизации в сельском хозяйстве. В 1913 г. средняя урожайность пшеницы составила в России 8,8 u/ гa - в Германии она была в 3 раза выше. Более $50 \%$ крестьянских хозяйств не имели плугов, обрабатывая землю сохами и косулями. В 1913 г. в России имелось лишь 152 трактора. В США к тому времени их было несколько тысяч, а к концу 1919 г. только компания Форда выпускала около 90 тыс. тракторов в год.

Гражданская война и вызванная ей разруха значительно увеличили разрыв между Россией и ведущими западными державами во всех областях промышленного и сельскохозяйственного производства.

После прекращения военных действий правительство Советской России уделило значительное внимание вопросам повышения эффективности сельскохозяйственного производства. Уже с 1921 года начала создаваться общегосударственная система семеноводства - «Госсемкультура», объединившая 
в своём составе областные с-х станции и бывшие помещичьи семеноводческие хозяйства. В 1923 году были образованы Институт экономики сельского хозяйства и Институт конъюнктуры, которые возглавили А. Чаянов и Н. Кондратьев. В 1924 году при Наркомземе организовалось Бюро по сортоиспытаниям, вскоре создавшее две сортоиспытательных сети - Северную (зав. В.Е. Писарев) и Южную (зав. В.В. Таланов). 8 августа 1924 года Президиум ЦИК принял постановление о создании Всесоюзной академии для координации и руководства научно- исследовательскими работами в области сельского хозяйства. 16 июня 1925 года СНК утвердил положение об Институте прикладной ботаники и новых культур (ИПБиНК), которому было поручено систематическое изучение растительных ресурсов России и других стран, сбор семян и интродукция сельскохозяйственных культур, селекция и сортоиспытания, разработка новых приёмов агротехники. 25 июня 1929 года была создана намеченная пять лет назад сельскохозяйственная академия - ВАСХНИЛ.

Эти учреждения вели обширные научно - исследовательские и опытные работы в области сельского хозяйства. За вторую половину 1920-х гг. штат ИПБиНК (с 1930 года Всесоюзный институт растениеводства - ВИР) расширился до 1200 человек, он стал крупнейшим научным учреждением Советского Союза и одним из самых крупных в мире. В системе ВАСХНИЛ было создано три с половиной десятка исследовательских институтов: Институт сахарной свеклы, Институт лубяных культур, Институт хлопкомасличных культур,.... К 1934 году в систему ВАСХНИЛ входило 407 опытных учреждений, в которых работало 11 тысяч научных и технических сотрудников.

Наряду с организацией научно-исследовательской и опытной работы в сельском хозяйстве, правительство немало внимания уделяло проблеме его механизации. С 1921 года в Советскую Россию начали поставляться тракторы Форда - Фордсоньл. В январе 1926 года СССР закупил десять тысяч Фордсонов, а всего за 1921- 27 гг. в Советский Союз их было поставлено около 24 тысяч.

Начал решаться вопрос создания собственной тракторной промышленности. С 1924 года на Путиловском заводе был налажен выпуск аналогов тракторов Форда, названных Фордсон-Путиловец. Их построили около 40 тыс.; во второй половине 1920-х гг. Фордсон-Путиловеи был самым распространённым трактором в советском сельском хозяйстве.
Курс на промышленное развитие страны одобрялся в тогдашней Советской России не всеми. В первой половине 1920-х гг. среди левого крыла большевистской партии были популярны теоретические установки троцкизма, согласно которым в ближайшее время ожидалась мировая, или, по крайней мере, общеевропейская революция. После чего победивший пролетариат разных стран мог бы организовать, так сказать, разделение труда: в Германии развивать индустрию; в России - аграрный сектор. Из чего делался закономерный вывод: развивать России собственную индустрию нет необходимости. (Отражением такого подхода было, например, предложение видного троцкиста Ю. Ларина ${ }^{1}$ ликвидировать в России авиапромышленность: «авиазаводы подобны фабрикам духов и помады, в которых не нуждается Советское государство»²). Провалы попыток установления власти пролетариата в Германии - подавление путча «спартаковцев» в Берлине (январь 1918 г.); ликвидация Баварской Советской республики (май 1919 г.); неудача Гамбургского восстания (октябрь 1923 г.) - отодвинули на второй план перспективы мировой революции, а заодно понизили «акции» Троцкого в Советской России. Однако лишь его политическое поражение в середине 1920-х гг. и последующее изгнание из страны позволили сталинскому руководству развернуть форсированную индустриализацию. Во второй половине 1920-х гг. задача создания собственной тяжёлой промышленности, включавшей выпуск автомобилей и тракторов, была поставлена в планы пятилеток. К концу первой пятилетки СССР создал свою машиностроительную базу, которая удовлетворяла основные потребности народного хозяйства в новой технике.

17 июня 1930 г. сошёл первый трактор с нового Сталинградского тракторного завода- гиганта. В 1931 году в сельское хозяйство СССР поступило около 60 тыс. тракторов.

Для облегчения доступа крестьянских хозяйств и колхозов к новой технике по всей стране начала создаваться сеть машинно- тракторных станций. К лету 1930 года действовало 158 государственных и

\footnotetext{
${ }^{1}$ Ларин Ю.М. (Лурье Михаил Залманович) - профессиональный революционер; в с-д. движении с 1900 г. В августе 1917 г. перешёл из «межрайонцев» (троцкисты) в РСДРП (б). После октября 1917 г. член Президиума Высшего совета народного хозяйства (ВСНХ) РСФСР. Тесть Н.И. Бухарина.

2 цит. по Велижев А.А. «Достижения советской авиапромышленности за 15 лет», М.-Л., 1932 г., стр. 12
} 


\section{Национальная безопасность 3(26) • 2013}

479 кооперативных МТС. Всего за первую пятилетку было создано около 2,5 тыс. МТС. К 1937 году, концу второй пятилетки, в хозяйствах МТС находилось около 365 тыс. тракторов; 105 тыс. зерноуборочных комбайнов; 60 тыс. грузовых автомобилей.

В 1927 г. 28,3\% крестьянских хозяйств РСФСР не имели рабочего скота, 31,6\% - пахотного инвентаря, $19,2 \%$ - коров ${ }^{3}$. Безлошадные крестьяне одалживали лошадей, на условиях, в средней полосе России, «пуд в день». Полная обработка десятины занимала 12-15 рабочих дней лошади, и, если крестьянин брал взаймы ещё и инвентарь, ему приходилось отдавать до $1 / 2$ всего урожая. Из-за низкой урожайности запасы хлеба во многих крестьянских хозяйствах заканчивались в феврале- марте; его приходилось также занимать, на кабальных условиях: «пуд на пуд или рубль на рубль» (100\% сезонных, не годовых).

Постройка тракторных заводов, массовый выпуск автомашин, создание сети МТС решили, в целом, вопрос механизации сельскохозяйственного производства. Вместе с тем, для освоения этой и другой новой техники, поставлявшейся в разные отрасли народного хозяйства, требовалась подготовка многочисленных квалифицированных кадров. Она была начата под известным лозунгом: «Кадры решают всё».

28 декабря 1934 г., выступая в Кремле на приёме в честь металлургов, Сталин заявил: «Если раньше однобоко делали ударение на технику, на машины, то теперь ударение надо делать на людях, овладевших техникой». На приёме в Кремле в честь выпускников военных академий 4 мая 1935 г. он же сказал: «надо было пойти на жертвы и навести во всем жесточайшую экономию, надо было экономить и на питании, и на школах, и на мануфактуре». Теперь голод в области техники позади, страна вступила «в новый период, я бы сказал, голода в области людей, в области кадров». Напомнив о лозунге «кадры решают всё», Сталин призвал «наконец, понять, что из всех ценных капиталов, имеющихся в мире, самым ценным и самым решающим капиталом являются люди, кадры».

Задача подготовки специалистов, владеющих новой сельскохозяйственной техникой, решалась путём расширения сети средних и высших агротехнических образовательных учреждений; организации курсов трактористов; массового выпуска профильной литературы; общего повышения грамотности и культуры на селе.

${ }^{3}$ «История советского крестьянства», т. 1, 1986 г., стр. 330
К концу второй пятилетки в СССР было 87 сельскохозяйственных вузов и 515 техникумов; за две пятилетки было издано 419 млн. экземпляров книг по сельскому хозяйству; выходила специальная «Крестьянская газета». В селе организовывались избы- читальни; велась пропаганда агротехнических новшеств; для приучения крестьян к самостоятельной постановке сельскохозяйственных опытов создавались хаты-лаборатории ${ }^{4}$.

С начала 1930-х гг. в стране развёрнулось движение передовиков производства, распространившееся и на сельское хозяйство. В 1933 году Паша Ангелина, дочь батрака, окончившая курсы трактористов, организовала первую женскую тракторную бригаду на МТС. В 1933- 34 гг. её бригада заняла первое место по МТС, выполнив план на 129\%. Призыв к освоению колхозницами новой техники был подхвачен, и к 1938 году на тракторы пересели 200 тыс. женщин.

Движение передовиков получило поддержку руководителей страны. В 1935 году прошёл Всесоюзный слёт передовиков сельского хозяйства (на нём выступила Паша Ангелина). В ноябре 1935 года в Кремле состоялся приём в честь колхозниц- ударниц свекловичных полей (на нём выступила Марьяна Демченко). В декабре 1935 года состоялась встреча руководителей страны с передовиками урожайности по зерну, трактористами и машинистами молотилок. Ударники и новаторы производства прославлялись в прессе, чествовались на торжествах, избирались в высшие представительные органы.

Наряду с механизацией сельского хозяйства, в СССР в 1930-х гг. внедрялись передовые агротехнические приёмы повышения урожайности, в т.ч.: травопольные севообороты (под руководством академика В.Р. Вильямса), посадки защитных лесополос (в 1931- 41 гг. было посажено около 450 тыс. га полезащитных насаждений и водоохранных лесов); осуществлялись крупные ирригационные проекты.

Предпринятые в 1930-х гг. руководством СССР усилия по форсированной механизации сельского хозяйства, освоению новой техники, поддержке агротехнических работ имели своими результатами расширение посевных площадей, повышение сбора основных зерновых культур, увеличение поголовья скота. С 1 октября 1935 г. была восстановлена сво-

\footnotetext{
${ }^{4}$ Среди работников таких хат-лабораторий был и знаменитый позже создатель системы почвозащитного земледелия, «народный академик» Терентий Мальцев.
} 
бодная продажа мяса, жиров, сахара, картофеля. В 1937 г. было собрано 97 млн. тонн зерновых, что значительно превышало рекордный довоенный сбор (80 млн. в 1913 г.). В 1938 г. посевная площадь по сравнению с 1913 г. увеличилась на 8 млн. га, при этом весь прирост пошёл на расширение посевов наиболее ценной зерновой культуры - пшеницы. К началу 1938 г. поголовье крупного рогатого скота увеличилось, по сравнению с 1 января 1933 г., с 33,5 до 50 млн.; свиней с 9,9 до 25,7 млн. СССР стал производить 30\% мировой продукции пшеницы, 56\% ржи, $24 \%$ ячменя, $80 \%$ гороха и чечевицы.

Перемены, происшедшие в сельском хозяйстве СССР, обратили на себя внимание и политических противников сталинского режима. Троцкий в книгах «Преданная революция» и «Преступления Сталина» отмечал, среди прочего, что СССР вышел на первое место в мире по производству тракторов, а урожайность пшеницы к 1935 году повысилась с 8 до 13 uү/гa.

Несколько хуже поначалу обстояли дела в области селекции, сортоиспытаний, интродукционной работы. Большие капиталовложения, сделанные с середины 1920-х гг. в ведущие научно- исследовательские сельскохозяйственные организации - ВИР и ВАСХНИЛ - дали за десятилетие весьма незначительную практическую отдачу 5 . Руководство страны усмотрело в этом политический саботаж со стороны академических работников, возглавлявших эти организации ${ }^{6}$, что привело в середине 1930 -х гг. к кадровым перестановкам в них.

Вместе с тем, в те же 1930-е годы, откликаясь на социальный заказ, стало появляться всё больше специалистов, активно включавшихся в решение проблем страны. Среди сельскохозяйственников широкую известность и поддержку на государственном уровне получил молодой агроном Т.Д. Лысенко, предложивший ряд оригинальных агротехнических приёмов повышения урожайности и подчёркивавший необходимость быстрого внедрения достижений науки в производство.

Яровизация пшеницы, наиболее известное из ранних достижений Т.Д. Лысенко, была открыта им в конце 1920-х гг. и стала широко внедряться в стра-

\footnotetext{
${ }^{5}$ Так, в статье «Правды» от 4 октября 1937 года «На старых позициях» отмечалось, что громадные средства, выделенные на экспедиции ВИРа, не оправдали себя; что институт, вместо сортов, дал сотни монографий и ботанических описаний

${ }^{6}$ формирование их руководящего состава в середине 1920-х гг. находилось под сильным влиянием троцкистов (Горбунова, Муралова, Яковлева,...)
}

не, повышая урожайность на 1-2 u̧/2а. В 1936 году Т.Д. Лысенко предложил метод чеканки - удаления верхушек - хлопчатника, позволивший увеличить сбор хлопка (культуры, важной и для военного производства) на 10-20\%. Он нашёл простое решение проблемы посадки в южных районах СССР картофеля, который там быстро вырождался и давал невысокие урожаи. Т.Д. Лысенко предложил сажать его в летнее время. В результате в южных районах повысилась урожайность картофеля и улучшились его сортовые качества. Видный руководитель сельского хозяйства СССР 1960- 80 гг., автор ряда книг о земледелии, Ф.Т. Моргун писал: «Хорошо помню, что в довоенные годы мы, жители Донбасса, наелись картофеля только тогда, когда начали сажать эту культуру в середине лета: в июне и июле. Этот метод предложил академик Лысенко...». В марте 1941 года за разработку и внедрение методики летних посадок картофеля Т.Д. Лысенко вместе с группой коллег была присуждена Сталинская премия первой степени 8 . В 1939 году Лысенко разработал новую агротехнику проса - широкорядный посев в сочетании с усиленной борьбой с сорняками - позволившую увеличить урожайность этой культуры с 8-9 до 15-20 центнеров с гектара. В 1940 году просо по его агротехническим рекомендациям высевалось на 700 тыс. га. В 1938 году Т.Д. Лысенко возглавил Всесоюзную академию сельскохозяйственных наук, сменив на этом посту профессионального революционера А.И. Муралова 9 .

Кадровые перестановки второй половины 1930 -х гг. в руководстве ведущими аграрными научно- исследовательскими учреждениями благоприятно отразились на уровне селекционных работ в СССР. В 1937- 40 гг. кубанский селекционер озимых пшениц П.П. Лукьяненко вывел ряд новых сортов, устойчивых к ржавчине и превы-

\footnotetext{
${ }^{7}$ Моргун Ф.Т. «Академик Трофим Лысенко: каким он был в действительности», Полтава, 2007 г., стр. 26.

${ }^{8}$ По свидетельству родственников Трофима Денисовича, он долго не брал свою часть премии, за что, в конце концов, получил замечание от Сталина. В июне же, когда началась война между СССР и Германией, он перечислил причитавшуюся ему денежную часть премии на нужды фронта.

${ }^{9}$ Муралов Александр Иванович (1886 - 1937 гг.). Член РСДРП с 1905 г. С 1929 г. наркомзем РСФСР; с марта 1933 г. зам. наркомзема СССР; с июня 1935 г. президент ВАСХНИЛ. Его брат Муралов Н.И. (1877 - 1937 гг.), член РСДРП с 1903 г., в 1925- 27 гг. являлся ректором сельхозакадемии имени Тимирязева; в январе 1937 г. был одним из главных обвиняемых по делу «параллельного троцкистского центра».
} 
шавших по урожайности использовавшиеся ранее на 5-7 u̧/2a. В 1940 году он был награждён Большой серебряной медалью ВСХВ. В 1940- 41 гг. агроном В.С. Пустовойт создал новый урожайный и высокомасличный, устойчивый к волчку и другим болезням, сорт подсолнечника. На Грибовской овощной селекционной станции вывела ряд сортов капусты Е.М. Попова, награждённая в 1939 г. Малой серебряной медалью ВСХВ. В марте 1941 г. одесский селекционер Д.А. Долгушин за разработку методов получения элиты зерновых культур был награждён Сталинской премией второй степени. Сотрудник Азербайджанской опытной станции И.С. Варунцян вывел ценные сорта хлопчатника, районированные в Закавказье, а А.Г. Лорх и П.С. Гусев из подмосковного НИИ картофельного хозяйства создали новые сорта картофеля, отмеченные премиями и золотыми медалями ВСХВ.

Эти селекционные достижения и агротехнические приёмы давали повышение урожайности основных сельскохозяйственных культур, использовавшихся для питания населения и в качестве технического сырья в промышленности, и их внедрение повышало продовольственную безопасность страны.

\section{Продовольственная проблема во время войны}

Проведённые в предвоенное десятилетие общегосударственные мероприятия в области сельского хозяйства - массовая механизация, подготовка квалифицированных специалистов, селекция новых сортов, внедрение агротехнических приёмов повышения урожайности - заложили прочные основы сельскохозяйственной безопасности Советского Союза, позволили добиться обеспечения населения продуктами питания первой необходимости, а промышленности - нужным сырьём из технических культур. Были созданы стратегические резервы пшеницы, ржи, проса.

Сельскохозяйственная экономика, построенная в СССР в 1930-х гг., имела и значительный мобилизаиионный ресурс. Её ключевые принципы - централизованное планирование, колхозно-совхозная система - неоднократно критиковавшиеся с хозяйственной и либеральной точек зрения, в полной мере проявили свои достоинства во время войны. Полумилитаризованная организация крупнотоварного производства в колхозах и совхозах, работавших по плановым заданиям, обеспечила их быстрый пере- ход к решению задач военного времени. Между тем, сомнительно, чтобы такой переход успешно совершили - особенно в условиях блицкрига, тотальной войны, необходимости срочной эвакуации и затем быстрого восстановления деятельности на новых местах - разрозненные крестьянские хозяйства, работающие на рыночных принципах.

Разумеется, это относилось не только к сельскому хозяйству. Сразу после начала войны промышленность страны начала переводиться на военные рельсы, а оказавшиеся в опасности заводы эвакуироваться на восток. Об эффективности этой работы, например, в авиастроении, одной из наиболее сложных отраслей производства, требующей взаимодействия многих предприятий, говорит следующий факт, приведённый авиаконструктором А. Яковлевым: авиапромышленность СССР выпустила в 1941 г. 15735 самолетов, в 1942 г., в условиях эвакуации авиационных заводов, - 25 436, в 1943 г. - 34 900, в 1944 г. - 40300. В 1944 г. выпуск самолётов в СССР по сравнению с довоенным временем увеличился в 3,8 раза ${ }^{10}$.

Наконец ещё одним фактором, обеспечившим эффективную работу советского сельского хозяйства (как и других отраслей) во время войны, была предвоенная кадровая политика: поддержка новаторов и передовиков, выдвижение специалистов, нацеленных на конечный результат, на быстрое внедрение достижений науки в производство.

Уже летом 1941 года, вскоре после начала войны, из-за стремительного наступления немецких войск, страна потеряла важные сельскохозяйственные районы Украины. Под угрозой оказался Краснодар и другие традиционные житницы. Основное производство зерна пришлось разворачивать на востоке $\mathrm{CCCP,} \mathrm{в} \mathrm{Сибири} \mathrm{и} \mathrm{Казахстане.} \mathrm{Из} \mathrm{западных} \mathrm{областей}$ были эвакуированы колхозные запасы, инвентарь, скот, материал селекционных станций ${ }^{11}$.

Налаживание сельскохозяйственного производства в восточных регионах проходило при нехватке рабочих, техники, горючего. В этих условиях женщины- колхозницы, освоившие в 1930-х гг., по инициативе Паши Ангелиной и других передовиков, тракторы и зерноуборочные комбайны, заменили

\footnotetext{
${ }^{10}$ А.С. Яковлев с 1940 г. был заместителем наркома авиапромышленности.

${ }^{11}$ Так, селекционер П.П. Лукьяненко вывез из оказавшегося под угрозой захвата немецкими войсками Краснодара сортовой материал пшеницы, из которого им были вскоре выведены новые высокоурожайные сорта.
} 
ушедших на фронт мужчин. Сама Ангелина возглавила женскую тракторную бригаду в Казахстане.

Капризы погоды, другие проблемы сельского хозяйства Сибири и Казахстана, требовали грамотных рекомендаций опытных специалистов, способных быстро находить правильные решения в нестандартных ситуациях. Новые руководители советской аграрной науки, сменившие в середине 1930-х гг. профессиональных революционеров и занятых изучением мировых проблем академиков, превратили ВАСХНИЛ в оперативный штаб по решению срочных сельскохозяйственных вопросов и поиску дополнительных источников сырья. Тогдашний президент ВАСХНИЛ Т.Д. Лысенко ${ }^{12}$ писал: «всю свою научную деятельность и работу всего коллектива, тесно со мной работающего, мы направили исключительно на решение сугубо важных научных вопросов, помогающее в тяжёлье дни войны колхозам и совхозам увеличивать продовольственные и сырьевые ресурсы страны... В военное время колхозы и совхозы особенно остро чувствуют потребность в помощи агробиологической науки. Война потребовала от сельского хозяйства быстрого решения больших $и$ мальх вопросов, направленных на удовлетворение возросших нужд нашей страны, нашей доблестной Красной Армии в пищевых и сырьевых ресурсах» ${ }^{13}$.

Так, летом 1941 года возникла угроза потери урожая из-за морозобойности зерна ввиду прогноза наступления ранних осенних заморозков в восточных областях СССР. Вымерзание значительной части зерновых на востоке, в условиях, когда западные житницы страны находились под немецкой оккупацией, имело бы катастрофические последствия. Поскольку в этом случае «виновата» была Природа то, казалось бы, земледельцы сделать ничего не могут. Однако специалисты ВАСХНИЛ нашли выход. Во второй половине августа 1941 года они проанализировали состояние посевов пшеницы в районах Сибири и Северного Казахстана, а также сопоставили данные за разные годы о температуре, осадках, времени наступления первых осенних заморозков. Был сделан вывод, что пшеница осенью 1941 года полностью дозреть не успеет. Затем в виде опыта в нескольких

\footnotetext{
12 для оперативного руководства сельским хозяйством он был назначен также главным агрономом наркомата земледелия

${ }^{13}$ Переработанная стенограмма отчётного доклада на общем собрании академиков и членов-корреспондентов Академии наук СССР в Свердловске 6 мая 1942 года.

Т.Д. Лысенко «Агробиология», М., 1952 г., стр. 404-414.
}

хозяйствах в 20-х числах августа на небольших площадях была скошена ещё недозрелая пшеница. Опыты проводились практически одну неделю. После чего Т.Д. Лысенко принял решение: рекомендовать хозяйствам Сибири и Северного Казахстана, не дожидаясь полной зрелости яровых, в конце августа приступить к их раздельной уборке, начиная с наиболее зрелых участков, а затем, с 5 - 10 сентября, скашивать все участки зерновых, независимо от их зрелости. Предложение было реализовано и основной урожай был от заморозков спасён ${ }^{14}$.

Затем возникла новая проблема. В конце зимы 1942 года выяснилось, что в ряде районов восточных областей СССР многие семенные партии зерновых имеют низкий уровень всхожести семян, иногда порядка 30 - 40\%. На это не обращали внимания раньше, когда основной урожай зерновых давали западные области страны, а восточные играли вспомогательную роль. Теперь же положение изменилось. Т.Д. Лысенко с сотрудниками разработали простой метод, с помощью которого у некондиционны по всхожести семена пшеницы и других зерновых хлебов можно было повысить всхожесть до первого класса. Именно, из их экспериментов выяснилось, что некондиционность семян зерновых хлебов часто являлась следствием не гибели зародышей, а того, что они, попав сразу после уборки в холодные морозные условия, характерные для Восточной Сибири и Казахстана, не успевали закончить к посеву своё дозревание и уходят в глубокий покой. Было предложено с наступлением весны как можно быстрее выгрузить из зернохранилищ колхозов семена пшеницы наружу и рассыпать их тонким слоем на брезент, мешковину и другие подстилки, чтобы их обогрело солнце и наружный воздух. В результате, при температуре $5-15^{\circ}$ семена за одну- две недели успели дозреть и степень их всхожести существенно повысилась. Этот способ получил название "воздушно- теплового обогрева семян”. В ряде случаев она составила 90,95 , и даже $99 \%$ - вместо прежних $30-40 \%$.

Одной из важнейших культур в структуре питания населения СССР в то время являлся картофель.

\footnotetext{
14 Заморозок в период налива зерна прекращает этот процесс, в итоге получается морозобойное зерно, представленное пленочной оболочкой без эндосперма, т.е. белка, клейковины и т.д. Если до наступления ранних заморозков скосить посевы пшеницы в валки, то заморозок будет неопасен, т.к. растения будут частично обезвожены и процесс оттока питательных веществ, т.е. налив зерна, будет продолжаться в нормальном режиме.
} 


\section{Национальная безопасность 3(26) • 2013}

Он был прост в посадке и уходе, хорошо сочетался со многими другими продуктами; недаром его называли “второй хлеб”. Кроме того, картофель давал с единицы площади урожай больший, чем почти все остальные сельскохозяйственные культуры. Однако во многих регионах страны, особенно на востоке и юго-востоке, имелось мало посадочного материала картофеля.

Осенью 1941 года группа специалистов ВАСХНИЛ во главе с Т.Д. Лысенко разработала методику посадки картофеля верхушками клубней. С клубня срезалась верхушка 10-15 грамм, оставляемая для посадки; остальная часть использовалась для питания. Была составлена инструкция населению, как хранить до весны, проводить предпосадочную яровизацию и сажать верхушки картофеля. Всем предприятиям общественного питания и промышленности, использовавшим сырой картофель, было предписано срезать и хранить верхушки. Агробиологи консультировали население и организации по оптимальному хранению верхушек клубней для посадки в будущем году и вели разъяснительную работу по внедрению этого метода.

Применение метода посадки верхушек клубней картофеля дало значительную прибавку к урожаю, что было особенно важно в военное время. Весной 1942 года верхушки от продовольственных клубней картофеля были посажены в одной лишь Сибири на площади более 150 тысяч гектаров. Верхушки картофеля сажались не только в централизованных хозяйствах, но и на индивидуальных огородах рабочих, служащих, колхозников. В результате в стране в 1942 году дополнительный урожай картофеля составил не менее 200 тысяч тонн ${ }^{15}$. Нелишне отметить, что картофель в то время применялся при изготовлении нитропороха, использовавшегося в запальном устройстве знаменитых “катюш”, и имел, таким образом, не только пищевое, но и важное военное значение.

В 1943 году за разработку и внедрение методики посадки картофеля верхушками клубней коллективу учёных- сельскохозяйственников во главе с Т.Д. Лысенко была присуждена Сталинская премия.

Как и в прошлый раз, Т.Д. Лысенко перечислил свою часть премии на нужды фронта. Так же по-

\footnotetext{
${ }^{15}$ В начале 1942 года я тоже, перед чисткой картофеля, обрезал верхушки с глазками. Потом, следуя инструкции академика Т.Д. Лысенко, посыпал их печной древесной золой, проводил яровизацию, а весной высаживал в грунт.
}

ступили и его коллеги. От имени Верховного главнокомандующего И.В. Сталина им была послана телеграмма с благодарностью.

В 1942- 43 гг. специалисты ВАСХНИЛ во главе с Т.Д. Лысенко изучали методы определения всхожести семян. Способ анализа качества посевной партии, применявшийся зимой 1941/42 года, требовал довольно много времени. Т.Д. Лысенко и его коллеги нашли более быстрый и притом весьма простой способ определения степени всхожести семян. А именно, брались по $100-200$ семян из среднего для посевной партии образца, им давалось набухнуть в воде, затем с зародышей иглой снимались семенные оболочки (либо зародыши прокалывались иглой или булавкой) и семена ставились на проращивание. Если зародыши были живыми и только находились в состоянии покоя, то после этой процедуры они сразу начинали прорастать. Такой анализ позволял быстро определить процент всхожих семян в посевной партии и, соответственно, принять решение: применять метод весеннего воздушно- теплового обогрева для ускорения дозревания семян или же заменять партию.

В условиях нехватки трактористов и горючего Т.Д. Лысенко предложил сеять озимые по стерне ${ }^{16}$, утверждая, что остатки срезанных стеблей растений после уборки яровых будут способствовать задержанию снега и нормальному развитию растений. Хотя вначале его предложение было встречено с недоверием и даже с насмешками, оно оказалось полезным. Посевы по стерне озимой ржи дали немалую прибавку к урожаю, а также стали хорошим предшественником для последующих посевов яровой мягкой и твёрдой пшеницы.

Наконец, предложенная Т.Д. Лысенко агротехника проса позволила создать перед войной значительные запасы этой важной крупяной культуры, которая прочно вошла в рацион советских воинов ${ }^{17}$.

В июне 1945 года Т.Д. Лысенко было присвоено звание Героя Социалистического труда - высшая гражданская награда страны.

Одновременно с Т.Д. Лысенко звание Героя Социалистического труда получили такие вы-

\footnotetext{
${ }^{16}$ Стерня - невысокие остатки стеблей после уборки урожая.

${ }^{17}$ Между прочим, пшённая каша является одним из немногих пищевых продуктов, способных связывать продукты гидролиза лекарств, особенно антибиотиков, и выводить их из организма. Поскольку в фронтовых условиях антибиотики применялись постоянно, то пшённая каша приносила там пользу и как целебный, способствовавший выздоровлению раненых, продукт.
} 
дающиеся советские учёные как академики И.М. Виноградов, И.И. Мещанинов, А.Н. Бах и другие.

По свидетельству Ю.Т. Лысенко, когда на заседании правительства, где обсуждалось присвоение званий Героя Социалистического труда, своих кандидатов предложила Академия наук СССР, Сталин, который вёл заседание, осведомился: “Лысенко в списке есть?” Представитель академии, смутившись, ответил: “нет”. “Включить”, распорядился Сталин. Кто-то из собравшихся спросил: “за что?” Имелось в виду, понятное дело, уточнение формулировки к постановлению о награждении, но Сталин подумал, что ему возражают, и возмущённо воскликнул: “Как это - за что?? Да хотя бы за заготовку проса - мы всю войну кормили армию этим просом!"

Вклад, внесённый сотрудниками ВАСХНИЛ в решение продовольственной проблемы в годы войны, в организацию работ по обеспечению населения и промышленности продуктами и растительным сырьём, был отмечен в №2 журнала “Вестник Россельхозакадемии” за 2005 год, посвящённом 60-летию победы в Великой Отечественной войне. В статье "Работа Академии в военное время" к.и.н. А. Мирошниченко, начальник отдела документального обеспечения (научного архива) Россельхозакадемии, писал: "Исторические архивные документы свидетельствуют о том, что Академия <ВАСХНИЛ $>$ в военное время справилась со стоявшими перед ней задачами. Институты выполнили много научных исследований, предложили разработки, внедрение которых в совхозах и колхозах дало возможность в кратчайшие сроки увеличить производство продовольствия и сельскохозяйственного сырья в Восточных районах страны, а также в районах, освобождённых от немецикой оккупациии".

Наряду с разработкой экстренных агротехнических рекомендаций для колхозов и совхозов, советские специалисты- сельскохозяйственники продолжали вести, несмотря на тяжёлые условия эвакуации или прифронтовой обстановки, селекционные и сортоиспытательные работы. Так, П.П. Лукьяненко уже в 1944 году, вернувшись в Краснодар из Алма-Аты, создал новый сорт Скороспелка 2, а через год - ещё более урожайный - Новоукраинка 83. Он был награждён медалью “За доблестный труд в Великой Отечественной войне”. В 1946 году за эти работы ему была присуждена Сталинская премия второй степени. Е.М. Попова, работая на Грибовской овощной селекционной станции (Подмосковье), в 1943 году предложила для районирования сорта капусты Белорусская 455, Московская поздняя 15, Амагер 611, которые стали брэндами отечественной селекции. Эта работа имела особенно важное значение, потому что капуста в годы войны стала для населения важнейшей по значимости овощной культурой. Е.M. Попова была награждёна медалью “За доблестный труд в Великой Отечественной войне”, а в январе 1946 года за работу по улучшению старых и выведению новых сортов капусты ей была присуждена Сталинская премия второй степени. В те же военные годы на Грибовской селекционной станции были созданы сорта свеклы Бордо 237, моркови Нантская 4, которые до сих пор входят в Государственный реестр селекционных достижений; были получены, под руководством А.В. Алпатьева, скороспелые и холодостойкие штамбовые сорта томатов; под руководством В.К. Соловьёвой был создан ряд новых сортов гороха и бобов. При этом Грибовская станция в увеличенных объёмах продолжала выращивать и поставлять для нужд фронта и тыла семена овощных культур. Так, только в 1944 году по белокочанной капусте было выращено более 4 тонн элитных семян; а всего за годы войны было выращено и поставлено в овощеводческие хозяйства, в госпитали, заводам, огородникам более 60 тонн элитных и 300 тонн сортовых семян овощных культур. Кроме того, в годы войны Грибовская станция функционировала и как овощеводческое хозяйство, выращивая тонны овощей на нужды фронта. За производственные и научные достижения в 1942 и 1943 гг. приказом наркома земледелия РСФСР коллективу Грибовской овощной селекционной станции было присуждено переходящее Красное знамя и выдана денежная премия. В 1945 году директор станции Е.И. Ушакова была награждена орденом Ленина, с формулировкой в указе Президиума Верховного Совета СССР “За успешное выполнение заданий правительства в годы Великой Отечественной войны". Ведущие учёные Грибовской овощной селекционной станции были награждены орденами “Знак Почёта". Аналогичные примеры активной селекционной и семеноводческой работы в 1941-45 гг. можно было бы привести для многих научно-практических аграрных учреждений СССР.

Вели специалисты-сельскохозяйственники во время войны и другие исследования, направленные 
на обеспечение потребностей фронта и тыла: искали альтернативные источники питания для скота; разрабатывали методы получения белково-витаминной пасты из зелёных растений; изыскивали заменители дефицитных лечебных и дезинфицирующих средств; продолжали работы по улучшению сортов хлопчатника; выводили и районировали новые сорта чая в Закавказье и т.д.

25 июня 1945 года в Большом Кремлёвском дворце состоялся приём в честь участников парада Победы. На нём, кроме военачальников, присутствовали передовики предприятий, ударники колхозных полей, видные учёные нашей страны. Среди них были математик И.М. Виноградов, геолог В.А. Обручев, президент Академии наук ботаник В.Л. Комаров и многие другие. Сельскохозяйственников, внесших достойный вклад в победу, представлял президент ВАСХНИЛ Т.Д. Лысенко.

Курс на разработку новых агротехнических приёмов, повышение урожайности главных сельскохозяйственных культур сохранялся в советской аграрной политике некоторое время и после войны. По оценке видных американских биологов Р. Левонтина и Р. Левинса, в 1948 - 62 гг. урожайность зерновых росла в СССР наиболее быстрыми темпами ${ }^{18}$. В.Н. Ремесло и П.П. Лукьяненко создали сорта озимых пшениц Мироновская 808 и Безостая 1, с тавшие шедеврами мировой селекции и распространившиеся не только в СССР, но и во многих других странах. Благодаря работам B.C. Пустовойта по селекции подсолнечника, направленным на повышение его масличности и урожайности, к 1960-м гг. в нашей стране его выращивали вдвое больше чем во всём остальном мире, а советские сорта этой, исходно американской, культуры закупала даже Аргентина - родина подсолнечника. Грандиозный план создания восьми лесозащитных полос в Центральной России и на Украине общей протяжённостью 5320 км, начавший осуществляться с 1948 года, способствовал восстановлению сельского хозяйства в наиболее пострадавших от войны регионах. До принятия Н.С. Хрущёвым решения о крупномасштабном

\footnotetext{
18 «1948 - 1962 годы ... являлись периодом самого быстрого роста урожайности!», Levins R., Lewontin R., "The dialectical biologist”, 1985, p. 191. За 1948 - 1970 гг. средняя урожайность пшеницы в СССР увеличилась более чем на $120 \%$, в США менее чем на 90\% (цит. соч., таблица на стр. 190-191).
}

освоении целины и посеве кукурузы ${ }^{19}$, аграрная политика страны была направлена на развитие традиционных зернопроизводящих районов и имела целью расширение посевных площадей и повышение урожайности основных сельскохозяйственных культур - пшеницы и ржи. То есть, она следовала тому курсу, который позволил Советскому Союзу в 1930 - 40 -х гг. надёжно обеспечить свою продовольственную безопасность.

Автор выражает признательность Н.В. Овчинникову за помощь при работе над статьёй.

\section{Библиография:}

1. Велижев А.А. «Достижения советской авиапромышленности за 15 лет», М.-Л., 1932 г.

2. Вознесенский Н.А. «Военная экономика СССР в годы Отечественной войны», М., 1947 г.

3. «История советского крестьянства», т. 1, М., 1986 г.

4. Лысенко Т.Д. «Агробиология», М., 1952 г.

5. Мирошниченко А. «Работа Академии в военное время»// «Вестник Россельхозакадемии», №2, M., 2005 г.

6. Моргун Ф.Т. «Академик Трофим Лысенко: каким он был в действительности», Полтава, 2007 г.

7. Пивоваров В.Ф., Кононков П.Ф. «О вкладе коллектива Грибовской овощной селекционной опытной станции в победу в Великой Отечественной войне»// «Нетрадиционные сельскохозяйственные, лекарственные и декоративные растения», №1(5), М., 2010 г.

8. Федоренко А.Г. «Лукьяненко», М., 1984 г.

9. Levins R., Lewontin R., «The dialectical biologist», New York, 1985

\section{References (transliteration):}

1. Velizhev A.A. "Dostizheniya sovetskoy aviapromyshlennosti za 15 let", M.-L., 1932 g.

\footnotetext{
19 Урожайность пшеницы на освоенной с колоссальными затратами целине нельзя было назвать высокой: в 1954- 58 гг. она составляла, в среднем, 8-9 u/حa. После начала пыльных бурь, вызванных эрозией почвы, урожайности снизилась ещё больше: в 1961- 65 гг. она составила, в среднем, 6,1 u/гa. Одновременно в традиционных зернопроизводящих регионах России и Украины, из-за отсутствия средств, только за 1954 - 59 гг. вышло из сельскохозяйственного оборота свыше 13 млн. га пашни. В результате Советский Союз уже в 1963 году начал большие закупки зерна за рубежом.
} 
DOI: $10.7256 / 2073-8560.2013 .3 .5276$

При цитировании этой статьи сноска на dоі обязательна

Управление и обеспечение систем безопасности

2. Voznesenskiy N.A. "Voennaya ekonomika SSSR v gody Otechestvennoy voyny", M., 1947 g.

3. "Istoriya sovetskogo krest'yanstva", t. 1, M., 1986 g.

4. Lysenko T.D. "Agrobiologiya”, M., 1952 g.

5. Miroshnichenko A. "Rabota Akademii v voennoe vremya”//"Vestnik Rossel'hozakademii", №2, M., 2005 g.

6. Morgun F.T. "Akademik Trofim Lysenko: kakim on byl v deystvitel'nosti”, Poltava, 2007 g.
7. Pivovarov V.F., Kononkov P.F. “O vklade kollektiva Gribovskoy ovoschnoy selekcionnoy opytnoy stancii v pobedu v Velikoy Otechestvennoy voyne"// "Netradicionnye sel'skohozyaystvennye, lekarstvennye i dekorativnye rasteniya”, №1(5), M., 2010 g.

8. Fedorenko A.G. "Luk'yanenko", M., 1984 g.

9. Levins R., Lewontin R., «The dialectical biologist», New York, 1985 